\title{
CLÁUSULAS CONTRATUAIS GERAIS, CLÁUSULAS ABUSIVAS E O NOVO CÓDIGO CIVIL
}

\section{José de Oliveira Ascensão}

Professor Doutor da Universidade Clássica de Lisboa.

\begin{abstract}
SUMÁRIO: 1 A génese do "contrato de adesão"; 2 A génese das "cláusulas contratuais gerais"; 3 A génese do instituto das cláusulas abusivas; 4 A integração no conteúdo do contrato e o mútuo consenso; $5 \mathrm{O}$ erro; 6 A interpretação; 7 O conteúdo; 8 Critério de determinação das cláusulas proibidas; 9 A boa-fé: um pseudocritério; $10 \mathrm{O}$ enunciado legal; 11 Efeito sobre o contrato da existência de cláusula em infracção; 12 As limitações do sistema civil; 13 Superação do voluntarismo?
\end{abstract}

\section{A GÉNESE DO “CONTRATO DE ADESÃO”}

A problemática que nos propomos versar só se apreende devidamente se tivermos presente a viragem radical que no plano da fundamentação da validade dos negócios jurídicos foi realizada no séc. XVIII.

Anteriormente, a vinculatividade dos contratos estava dependente de um controlo da sua Justiça intrínseca. De tal maneira que na Idade Média Justiça e Direito quase se confundiam.

Mas o voluntarismo germina e desenvolve-se, acabando por ser acolhido como a causa geral da vinculatividade do Direito. No plano dos contratos trouxe a fundamentação destes na autonomia da vontade. O contrato vale porque foi querido pacta sunt servanda.

$\mathrm{O}$ individualismo e o liberalismo, a seguir triunfantes, levaram ao extremo esta orientação. $\mathrm{O}$ conteúdo dos contratos torna-se irrelevante: a obrigatoriedade destes assenta no consentimento, pois se a parte consentiu não se pode desvincular.

O relativismo, o positivismo e o formalismo, que se desenvolvem do séc. XIX e persistem até hoje, dão um bom caldo de cultura para esta visão. Só um vício do consentimento pode pôr em causa a validade do contrato. A Justiça é incognoscível: não é operacional como determinante da validade dos contratos.

Mas logo a partir do séc. XIX este paradigma começa a ser posto em causa, pelos resultados a que conduz.

Para o nosso tema, interessa-nos particularmente o que respeita ao que se chamou o contrato de adesão. A sociedade industrial trouxe as grandes concentrações urbanas e profundas desigualdades. Nasce a sociedade de massas. E nesta, é impossível manter a negociação individualizada dos contratos. Grande número de contratos passa a ser predisposto pela parte económico-socialmente mais forte, de modo que aos destinatários só resta aderir ou abster-se. O diálogo particular desaparece. 
Mas poderá ainda falar-se, nessas circunstâncias, em contrato? A que fica reduzida a autonomia privada?

De facto, não há para o aderente liberdade de criação de tipos negociais, nem liberdade de estipulação. Nem sequer há na maior parte dos casos liberdade económica de celebração, porque o aderente não pode prescindir de bens ou serviços essenciais.

Mas há a liberdade jurídica de celebração. Desde que o aderente consentiu, fica vinculado. Pacta sunt servanda.

A discussão desloca-se então, no séc. XIX e em todo o séc. XX, para a análise do consentimento do aderente. Pergunta-se se esse consentimento tem falhas que inquinem o contrato. Quer dizer, de início procura-se combater as grandes anomalias destes contratos, em que o predisponente se reserva sempre todas as vantagens, através do recurso a princípios gerais do direito.

Mas apenas se conseguem tímidos retoques, porque as ordens jurídicas não ofereciam meios de combate directo a essas situações. Não há praticamente cláusulas gerais para controlo do conteúdo dos contratos. Só restam por isso os pressupostos comuns dos negócios jurídicos:

- a capacidade do aderente;

- o objecto do consentimento e o conhecimento das cláusulas que este pressupõe;

- o erro;

- a interpretação negocial (e a integração).

1) No que respeita à capacidade, suscitam-se problemas em hipóteses tão banais como a do menor que viaja no ónibus. Como pode celebrar um contrato?

A questão não parece ter encontrado resposta no novo Código Civil brasileiro, ao contrário do que acontece em códigos europeus recentes.

Porém, a dificuldade não é específica do contrato de adesão. Manifesta-se em todos os actos da vida corrente que são praticados por menores. Por isso dispensamonos de o examinar especificamente neste lugar.

2) O desconhecimento do conteúdo do contrato representou o ponto principal do debate. Como dizer que o aderente consente quando as cláusulas lhe são comunicadas após a celebração do contrato? Ou quando estão afixadas nas paredes da loja? Ou quando se inserem em letra quase ilegível no verso do formulário?

Por outro lado, realisticamente, revela-se a impossibilidade prática de o aderente conhecer todas as cláusulas, porque se não, não chega a contratar: passa o tempo a ler clausulados. Todos nós, juristas ou não, celebramos afinal contratos sem tomar conhecimento das cláusulas predispostas.

3) Poderia pensar-se em invocar o erro. Mas, ainda que fosse possível, não seria remédio adequado. $\mathrm{O}$ aderente teria de pedir a anulação de cada contrato quando estivesse em erro. O que não é obviamente uma solução praticável. 
4) No domínio da interpretação, os melhores autores foram defendendo o princípio que a interpretação se deveria fazer contra o predisponente. Este tem a experiência que lhe permite formular as cláusulas que o defendam: se uma cláusula é ambígua, só a ele é imputável.

\section{A GÉNESE DAS “CLÁUSULAS CONTRATUAIS GERAIS”}

Tudo isto foi lento, penoso e insuficiente. A verdade é que os instrumentos gerais não eram adequados para resolver questões inteiramente novas.

Para além disso, havia uma ambiguidade na colocação da questão. Falando-se em "contrato de adesão", referia-se uma modalidade de contrato, caracterizada por ser imposto em bloco sem possibilidade de discussão pelos destinatários. Mas a questão era mais vasta, e diferente. Não se tratava de um tipo de contrato, mas de uma categoria de cláusulas. Bastava que uma cláusula fosse imposta ne varietur, ainda que todas as outras fossem objecto de negociação, para que a questão da maior força negocial se suscitasse. Não haveria então contrato (todo) de adesão, mas haveria cláusula(s) unilateralmente imposta(s).

Só com o Código Civil italiano em 1942 se dá o grande passo neste sentido. Este prevê as chamadas condições gerais dos contratos. E determina que as cláusulas onerosas devem ser expressamente aceites.

Se o avanço foi grande no que respeita à configuração do tema, não o foi na solução trazida. Esta é irrealista: é impossível que nos contratos de massa, nos serviços fundamentais como a água ou a electricidade, por exemplo, haja uma aceitação individualizada de cláusulas predispostas.

A lei alemã de 1978, chamada AGBGesetz, dá outro passo. Faz uma regulação mais completa, que se tornou paradigmática. E entra na valoração do conteúdo, determinando quando estas cláusulas gerais são proibidas.

Há porém que observar que, mais ainda talvez que a proteger o aderente, a lei alemã se destina a assegurar o tráfego jurídico. A primeira preocupação é impor que estas cláusulas se integrem no conteúdo do contrato. O critério determinante é colocado na cognoscibilidade: as cláusulas compõem o contrato, desde que ao destinatário seja dada a possibilidade de tomar conhecimento delas.

Temos assim consolidada a categoria das "condições gerais dos contratos", como cláusulas predispostas unilateralmente para uma generalidade de pessoas, que não têm possibilidade de discutir o seu conteúdo. As várias ordens jurídicas europeias foram regulando esta matéria.

A lei portuguesa trouxe um progresso no ponto de vista da designação, uma vez que passou a falar de "cláusulas contratuais gerais", em vez de "condições gerais dos contratos". Assim evita o termo condição, que é ambíguo. Poderia ter avançado mais no saneamento terminológico, se tivesse adoptado a epígrafe "cláusulas negociais gerais". Com efeito, pode haver cláusulas inalteravelmente predispostas em negócios 
unilaterais: seja o caso de valores mobiliários, como os relativos a derivados (futuros e opções). ${ }^{1}$

Ainda no domínio da terminologia, falamos em predisponente para designar aquele que dita inalteravelmente as cláusulas do negócio. Pouco interessa que, no rito negocial, ele apareça como o proponente ou o aceitante. Assim, nos contratos de seguros, a companhia surge formalmente como o aceitante de propostas que lhe são dirigidas. Mas é ela quem predispõe unilateralmente as cláusulas, e por isso é o predisponente.

Do outro lado está o aderente. A sua posição é sempre a de aderente às cláusulas contratuais gerais. A designação não implica qualquer retorno à figura do "contrato de adesão".

De todo o modo, a disciplina das cláusulas contratuais gerais evoluiu a partir daí no sentido de se concentrar sobretudo na determinação das cláusulas predispostas que deveriam ser proibidas. Ou através do controlo por cláusulas gerais, como a boafé, ou através de elencos de cláusulas inadmissíveis, ou por formas mistas, entra-se directamente na apreciação do conteúdo.

A categoria das cláusulas contratuais gerais não teve praticamente acolhimento no Brasil. Não o teve na lei; e a doutrina e a jurisprudência continuaram a referir o contrato de adesão, e não a categoria mais escorreita das cláusulas contratuais gerais.

Foi o contrato de adesão que veio a ter consagração legal no Código de Protecção e Defesa do Consumidor; e é ele que surge agora referido nos arts. 423 e 424 do novo Código Civil (NCC). ${ }^{2}$

Serão considerados nos lugares respectivos. Agora há que observar que, se bem que a técnica seja diferente, o "contrato de adesão" implica necessariamente cláusulas contratuais gerais. O seu conteúdo são estas cláusulas não sujeitas a discussão ou mudança. Por isso, a consagração do contrato de adesão traz zonas de coincidência com a técnica das cláusulas contratuais gerais.

\section{A GÉNESE DO INSTITUTO DAS CLÁUSULAS ABUSIVAS}

A partir da segunda metade do séc. XX surge novo instituto: o das cláusulas abusivas, por influência dominante do movimento de protecção do consumidor.

O consumidor é a parte negocialmente mais fraca. Há que protegê-lo contra cláusulas abusivas, porque emanação da maior força do fornecedor.

Mas o carácter abusivo da cláusula não está dependente de esta ser geral ou singular. Mesmo em contratos individualmente pactuados surgem cláusulas abusivas: aqui se dá a separação da técnica das cláusulas contratuais gerais. A questão estará então somente em determinar os critérios da abusividade das cláusulas.

1 Cf. o nosso Derivados (no prelo).

2 O art. 423 é objecto da proposta de alteração de RICARDO FIÚZA, que examinaremos mais tarde. 
Esta categoria foi irrompendo em numerosas leis de defesa do consumidor da Europa. É também aquela que acaba por receber consagração no Código de Protecção e Defesa do Consumidor brasileiro. ${ }^{3}$

A relação desta matéria com as categorias precedentes tornou-se difícil. O Código do Consumidor brasileiro a todas integra (embora as "cláusulas contratuais gerais só mediatamente, através dos contratos de adesão). Torna-se por vezes difícil determinar o que pertence a umas e outras.

O problema não é específico do Brasil. A Comunidade Europeia desenvolveu regras sobre as cláusulas abusivas nos contratos com consumidores. Essas regras vieram a ser transpostas para os ordenamentos internos, passando normalmente a figurar nos mesmos diplomas que regulavam já as cláusulas contratuais gerais. A coexistência não foi pacífica, porque as cláusulas abusivas individuais não se prestam à disciplina que foi estabelecida tendo em vista as cláusulas gerais. ${ }^{4}$

Mais especificamente dedicado à matéria das cláusulas abusivas, temos no Código do Consumidor o Capítulo VI (Da Protecção Contratual), Secções I e II.

A Secção I é intitulada "Disposições gerais" e a II "Das cláusulas abusivas". Mas da primeira secção constam disposições que tradicionalmente haviam sido associadas à problemática das cláusulas contratuais gerais, mas agora aplicadas também às cláusulas abusivas: como sejam a necessidade de conhecimento das cláusulas pelos consumidores (art. 46) e a interpretação destas da maneira mais favorável ao consumidor (art. 47). ${ }^{5}$

Entra-se depois nas cláusulas abusivas, indicando-se as que são nulas de pleno direito (art. 51). Não se referem às cláusulas gerais, cuja problemática é até muito ultrapassada; mas estas estão também seguramente abrangidas, desde que tenham conteúdo abusivo.

Por outro lado, não só se não exige que as cláusulas abusivas sejam gerais, como se admite que tenham sido objecto de negociação individual. O que é decisivo é o próprio carácter abusivo das cláusulas.

Perante isto, qual a posição do Código Civil?

Falar de um código que não entrou ainda em vigor é sempre uma tarefa de alto risco. Mas podemos dizer que a categoria da cláusula abusiva não é nele acolhida como tal. O que o código regula, aliás brevemente, nos arts. 423 e 424, são os contratos de adesão. Portanto, a lei civil só a esses contratos se aplicaria. Daqui resultaria que as regras sobre cláusulas abusivas continuariam a só beneficiar o consumidor.

3 Lei $n^{\circ} 8078$, de 11 de Setembro de 1990.

4 Cf. sobre esta matéria o nosso Cláusulas contratuais gerais, cláusulas abusivas e boa-fé, in Revista da Ordem dos Advogados (Lisboa), ano 60, II, Abr./00, 573-595; e in: separata à Revista Forense, vol. 352, 103-114.

5 Trata-se depois também dos escritos que vinculam o fornecedor (art. 48), do direito de desistência (art. 49) e da garantia contratual (art. 50). 
Mas surge uma dificuldade de grau maior. O Código do Consumidor, embora de modo tecnicamente incorrecto, generalizara já a todas as pessoas algumas regras que tinham sido inseridas visando aparentemente o consumidor só. O art. 29 do Código do Consumidor, que abre o Capítulo V (Das Práticas Comerciais), declara já que se equiparam aos consumidores todas as pessoas, determinadas ou não, "expostas às práticas" ${ }^{\circ}$ previstas nesse capítulo e no seguinte. O capítulo seguinte é o VI, donde consta a disciplina das cláusulas abusivas, que ora examinamos.

Essa disciplina era pois já genérica. Surge o Código Civil e omite-a, salvo no que respeita aos contratos de adesão. Devemos concluir que os restantes preceitos deixaram de se aplicar às pessoas que não forem consumidores?

Não houve revogação tácita, porque não há incompatibilidade. Também não houve revogação expressa, porque só o Código Civil e a $1^{\mathrm{a}}$ parte do Código Comercial foram revogados (art. 2.045 NCC). Poderia pensar-se na revogação global, resultante de uma matéria ter sido complexivamente regulada de novo. ${ }^{7}$ Mas as cláusulas abusivas e, mais genericamente, a valoração do conteúdo dos negócios não foram genericamente disciplinadas pelo NCC: há apenas fragmentos, em particular os relativos ao contrato de adesão.

Atrevemo-nos por isso a supor que as disposições gerais constantes do Código do Consumidor continuam em vigor. Pelo menos, tudo indica que isso está conforme a intenção do legislador, pois não se vê que o NCC pretendesse alterar a situação que resultava já do Código do Consumidor. Este fora aproveitado, na falta de aprovação do novo Código Civil, para actualizar alguns aspectos fundamentais da ordem jurídica brasileira.

\section{A INTEGRAÇÃO NO CONTEÚDO DO CONTRATO E O MÚTUO CONSENSO}

Passamos a examinar o regime global destas cláusulas resultante do Código do Consumidor e do NCC. Comecemos pelo ponto prioritário, que consiste em saber quando se consideram as cláusulas integradas no conteúdo do contrato.

Não se encontra regra que imponha que estas cláusulas sejam objecto de estipulação específica. ${ }^{8}$ A indagação passa então a centrar-se na suficiência da aceitação do destinatário. Nomeadamente, quando está em causa um contrato, como se pode dizer que se formou o acordo, ou mútuo consenso, das partes?

6 A expressão traz dificuldades de interpretação, mas abrange sem dúvida a exposição às cláusulas abusivas.

7 O Direito - Introdução e Teoria Geral - Uma Perspectiva Luso-Brasileira, $2^{\mathrm{a}}$ ed. bras. (12 ${ }^{\mathrm{a}}$ geral), Renovar (Rio de Janeiro), 2001, $\mathrm{n}^{\circ} 174$.

8 Exceptua-se o art. $18 \S 2^{\circ}$ do Código do Consumidor, que determina que nos contratos de adesão a cláusula de alteração do prazo de sanação do vício do produto deverá ser convencionada em separado, por manifestação expressa do consumidor. 
Este ponto é fundamental, mas o Código Civil nada diz. Pode por isso criar-se o cepticismo quanto à qualificação da relação assim formada como contratual. Mas por outro lado, se não há um contrato, como aplicar o regime contratual a estas situações, como toda a gente faz?

Verifica-se um recuo, consistente em exigir, em vez do conhecimento (e portanto o consentimento) efectivo, a mera cognoscibilidade como pressuposto do mútuo consenso. Assim procedia já o art. 1.341 do Código Civil italiano.

$\mathrm{O}$ art. 46 do Código do Consumidor exige que seja dada ao destinatário a oportunidade de tomar conhecimento prévio do conteúdo. Os contratos também não obrigarão se os instrumentos forem redigidos de modo a dificultar a compreensão. Ainda, o art. 54, $\S 3^{\circ}$ exige que os contratos de adesão escritos sejam redigidos em termos claros e legíveis; e o $\S 4^{\circ}$, que as cláusulas que implicarem limitações sejam redigidas com destaque, permitindo a sua imediata e fácil compreensão.

Vemos assim que se fez já o trânsito, do conhecimento efectivo para a cognoscibilidade e inteligibilidade fácil do conteúdo. Há muitas maneiras de ocultar uma informação; até serve para o efeito o excesso de informação, que disfarce no conjunto a cláusula que é juridicamente relevante. O Direito reage contra estes processos ardilosos.

Mas surge o Código Civil e nada se encontra, a propósito do contrato de adesão. Como proceder então?

Pode-se apelar para cláusulas de cúpula, como a boa-fé, que fora proclamada com generalidade imediatamente antes (art. 422, NCC). Mas o apoio em cláusulas tão gerais é inseguro, e por outro lado não é possível reconduzir todas as hipóteses em que não foi dado conhecimento prévio a condutas de má-fé.

Há que recordar que aqueles princípios do Código do Consumidor são já hoje apresentados como genéricos (art. 29); e que concluíramos que a intenção do NCC não foi a de os revogar. São trechos da disciplina civil, mas permanecem infelizmente fora da codificação civil.

Daqui resulta que estas cláusulas, sejam genéricas sejam individuais abusivas, devem ser apresentadas ao destinatário previamente à celebração do negócio, em condições de poder ser dele conhecidas. Se o não forem a consequência é radical: não se integram no conteúdo do contrato. Não são sequer inválidas, porque não chegam a ser conteúdo contratual.

$\mathrm{Na}$ mesma situação devemos considerar as überraschende Klauseln, por aparecerem em lugares surpreendentes do contrato. Isto vai contra a fácil apreensão da cláusula que a lei reclama. Em consequência a cláusula de surpresa não é inválida: mais do que isso, não produz efeito algum. Diríamos que é uma cláusula inexistente.

Mas uma coisa é a cláusula ser cognoscível, outra ter sido objecto do mútuo consenso.

É impossível falar de uma presunção de conhecimento das cláusulas cognoscíveis. A presunção exprime id quod plerumque accidit. A experiência diz-nos pelo contrário 
que é uma fatalidade que a quase totalidade dos contratos, pelo menos dos que contêm cláusulas contratuais gerais, sejam celebrados sem as pessoas tomarem conhecimento dos seus termos.

Isto nos leva para caminhos cada vez mais perigosos. O mútuo consenso é objecto de corrosão. Transita-se de um mútuo consenso sobre um conteúdo para um consenso na celebração do negócio, e não propriamente sobre as cláusulas constitutivas deste.

É um ponto que não podemos aprofundar. Pelo menos, haverá que pôr limites a esta suficiência do consenso a ficar vinculado por um contrato. Nunca poderia bastar um acordo em branco de sujeição a um contrato ou a cláusulas predispostas pela outra parte. Deve haver um consenso sobre a celebração de um certo contrato, sobre certo objecto. E para além disso, é essencial que no acordo se delimite um conteúdo económico determinado. Tudo o que se afastar do núcleo económico em que se acordou já está fora do mútuo consenso.

Ainda, e no que respeita às cláusulas contratuais gerais/contratos de adesão, a lei só admite essa forma de vinculação porque pressupõe que o predisponente estabelece o regime que está dentro da normalidade daquela relação. Essa é a contrapartida imposta pela ordem jurídica ao reconhecimento dum poder unilateral de regulação. Se as cláusulas saem da normalidade e o predisponente aproveita a sua maior força para sacrificar os destinatários, já as cláusulas predispostas não podem valer, porque deixam de satisfazer a ratio da norma que as admite.

\section{O ERRO}

Suponhamos que se ultrapassa essa fase. As cláusulas integram-se no conteúdo do contrato. E se, não obstante, o destinatário (que não tem o conhecimento efectivo do conteúdo) está em erro sobre elas?

Passa-se à problemática do erro, que é como dissemos uma das clássicas neste domínio. O erro, se relevante, seria um vício na formação de vontade. A ignorância duma dada cláusula equivaleria aqui ao erro, pois sempre haveria a falsa representação da realidade (mesmo que por incompleição).

Nos termos gerais, o erro terá de ser essencial para ser relevante. Que acontece pois, se o destinatário está em erro essencial quanto ao conteúdo do contrato?

Deverão concorrer ainda os demais pressupostos de relevância do erro. Será sobretudo importante saber se se deve exigir ou não a desculpabilidade do erro, que o NCC não refere expressamente (art. 138 e ss.). ${ }^{9}$

9 Cf. o nosso Direito Civil - Teoria Geral - II - Acções e Factos Jurídicos, $2^{\mathrm{a}}$ ed., Coimbra Editora, $2003, n^{\circ} 72$, em que concluímos que se o erro é censurável, o agente não pode prevalecer-se dele; mas se a contraparte for por sua vez censurável, por o erro ser reconhecível e ela não o ter reconhecido, a desculpabilidade do erro deixa de novo de ser exigida. 
Se mesmo o erro indesculpável viciar o negócio, haverá que nos interrogarmos sobre as consequências da leviandade do errante. Haverá então responsabilidade civil, nos termos da chamada culpa in contrahendo. Mas a responsabilidade tem efeito apenas sobre o dever de indemnizar. Não cria obstáculo ao exercício da faculdade de anulação do contrato - e apenas esta é o nosso objecto.

Mas, como dissemos já, ${ }^{10}$ o recurso ao erro, mesmo a ser admissível, só dá uma defesa muito escassa, particularmente no domínio dos contratos de massa. A anulação exige a iniciativa do destinatário da cláusula viciada: o art. 177, NCC, dispõe que a anulabilidade não tem efeito antes de julgada por sentença. Fica pois a anulação dependente de acção judicial. Na maior parte dos casos seria ruinoso intentá-lo, perante a exiguidade dos valores em jogo.

Deverá haver outros meios de protecção do destinatário das cláusulas.

\section{A INTERPRETAÇÃO}

Mesmo antes de haver lei, criou-se a tradição da interpretatio contra stipulatorem.

O art. 47 do Código do Consumidor determinou que as cláusulas contratuais serão interpretadas da maneira mais favorável ao consumidor. Dissemos já que esta é uma das disposições que foi generalizada, para aproveitar mesmo aos destinatários não consumidores (art. 29).

O NCC retoma esta matéria a propósito do contrato de adesão. O art. 423 dispõe que, havendo no contrato cláusulas ambíguas ou contraditórias, adoptar-se-á a interpretação mais favorável ao aderente. É uma regra de todo justificada, como dissemos, ${ }^{11}$ porque toda a dificuldade de interpretação é imputável ao predisponente.

Mas já há outro elemento a anotar. O Projecto Fiuza de alteração ao NCC atinge também este preceito. Para além da generalização, estabelece uma redacção mais favorável ao aderente; e elimina a restrição às cláusulas ambíguas ou contraditórias.

*Pode suscitar-se também a problemática da integração. ${ }^{12}$ Podem ter ficado pontos por regular no contrato, que todavia são necessários para a efectivação deste. Se os elementos verdadeiramente essenciais do contrato forem já definitivos - portanto, se há o acordo económico e a estruturação jurídica mínima que lhe corresponde - o contrato pode ser integrado, dentro do espírito do aproveitamento ou conservação dos negócios jurídicos.

12 Não discutimos aqui se se trata de verdadeira integração, se da chamada interpretação complementadora do contrato. 
Mas o mesmo critério básico continua aqui aplicável. A cláusula integranda, na dúvida, será a favorável ao aderente. O predisponente teve todas as condições para prever uma solução diferente. ${ }^{13}$

\section{O CONTEÚDO}

Chegamos ao ponto fundamental, que é o relativo ao próprio conteúdo destas cláusulas.

A situação que antecedeu o Código do Consumidor era difícil; só princípios gerais, sem concretização, permitiriam entrar na apreciação do conteúdo das cláusulas. Isto criava grande insegurança. ${ }^{14}$

O Código do Consumidor regula o contrato de adesão, mas é omisso quanto ao conteúdo das cláusulas. $\mathrm{O}$ preceito de maior interesse era o do art. $6 \mathrm{~V}$, que declara direito básico do consumidor a modificação das cláusulas contratuais que estabeleçam prestações desproporcionais ou a sua revisão em razão de factos supervenientes que as tornem excessivamente onerosas. Mas esta matéria é restrita ao direito do consumidor; escapa à generalização ex art. 29.

O NCC não acolheu nenhuma previsão da disciplina do contrato de adesão do Código do Consumidor. Apenas o Projecto Fiuza generaliza o $\S 3^{\circ}$, que integraria um novo $\S 1^{\circ}$ do art. 423. Mas mesmo este respeita à integração das cláusulas no conteúdo dos contratos, de maneira a serem compreensíveis pelos destinatários, e não ao conteúdo destas.

A novidade do NCC está no art. 424, que determina que são nulas no contrato de adesão as cláusulas que estipulem a renúncia antecipada do aderente a direito resultante da natureza do negócio.

O enunciado é difícil de interpretar. Os elementos que pertencem à natureza do negócio são típicos. Quererá dizer que se não pode renunciar antecipadamente a elementos do tipo?

Seja qual for a interpretação, o preceito deixa-nos perplexos. São dezenas as previsões de cláusulas proibidas que surgem nas leis modernas. Teremos de concluir que a lei brasileira só encontrou matéria de proibição nesta cláusula singular?

13 Matéria ainda conexa à da interpretação é a constante dos arts. 30 e 35 do Código do Consumidor, sobre a relevância da publicidade: obriga o fornecedor e permite, em caso de recusa, a rescisão do contrato. Mas esta regra não parece admissível fora dos contratos com consumidores. Por seu lado, o NCC não contempla estes pontos, nem sequer esclarece se a proposta deve ser interpretada de acordo com a publicidade do proponente. Mas a questão ultrapassa já a matéria das cláusulas que aqui nos ocupa.

14 Assim, Orlando Gomes alvitrou a hipótese da nulidade das cláusulas gerais (de contratos de adesão) que se afastassem de disposições supletivas. Não vemos nenhuma verosimilhança em semelhante entendimento, uma vez que se trata justamente de regras supletivas. O mesmo diremos da atribuição de um poder de revisão ao juiz, que nem tem base positiva nem seria desejável. Quanto ao recurso ao princípio geral da boa-fé, veja-se a crítica que adiante fazemos. 
Do art. 424 resulta porém um aspecto positivo: a nulidade que atribui à cláusula. Ficamos a saber que a consequência do recurso a cláusulas proibidas (ou à cláusula proibida) é a nulidade.

Porém, se o NCC pouco nos orienta no controlo do conteúdo das cláusulas, já nos parece ser muito importante a proximidade que existe no Código do Consumidor entre esta matéria e a das cláusulas abusivas. ${ }^{15}$

Dissemos que esta disciplina foi generalizada pelo Código do Consumidor. ${ }^{16}$ Dissemos também que entre as cláusulas abusivas se contam as cláusulas contratuais gerais abusivas. Como por outro lado já sabemos que não há que entender o laconismo do Código Civil sobre a matéria como significativo duma revogação, temos de concluir que o principal manancial a que recorrer para a determinação das cláusulas proibidas são hoje os arts. 51 a 53 do Código do Consumidor.

Passamos então a examinar os critérios legais de determinação das cláusulas proibidas.

\section{CRITÉRIO DE DETERMINAÇÃO DAS CLÁUSULAS PROIBIDAS}

Procurando caracterizar fundamentalmente o esquema legal, vemos que a consequência estabelecida coincide com a do NCC. O art. 51 do Código do Consumidor abre com as palavras: "São nulas de pleno direito...".

A lista das cláusulas contratuais relativas ao fornecimento de produtos e serviços é exemplificativa. Logo no proémio se diz que são nulas, "entre outras, as cláusulas...".

Isto está em sintonia com o que se passa noutras ordens jurídicas. Mas surpreende que não se dê um critério para determinação de essas outras cláusulas proibidas, contra o que estabelecem legislações em situação semelhante.

Afinal, esse critério surge de envolta com previsões singulares, no inciso IV do art. 51: são nulas as cláusulas que "estabeleçam obrigações consideradas iníquas, abusivas, que coloquem o consumidor em desvantagem exagerada, ou sejam incompatíveis com a boa-fé ou a equidade".

De facto, não há uma especificidade típica, há o mero enunciado de critérios gerais. Basta pensar que entre estes critérios ou qualificações se encontra a própria categoria que haveria que esclarecer - são abusivas as cláusulas que estabeleçam obrigações abusivas. Nada adianta como orientação neste domínio.

15 Embora se trate de uma proximidade que não originou o lançamento de referências. $\mathrm{O}$ art. 54, sobre contrato de adesão, segue imediatamente a disciplina das cláusulas abusivas, sem haver reciprocamente nenhuma remissão.

16 Salvo se razões particulares obstarem a essa generalização. Será o caso do art. $51 \S 4^{\circ}$, que faculta ao consumidor requerer ao Ministério que ajuíze a competente acção... Trata-se de típica regra de protecção do consumidor, não generalizável. Nas relações que se não estabeleçam entre fornecedor e consumidor, aplicam-se as regras normais. 
Tirando esta previsão inútil, resta ainda no preceito uma sobreposição de critérios. São nulas as cláusulas que estabeleçam obrigações:

- iníquas

- que importem desvantagem exagerada

- incompatíveis com a boa-fé

- incompatíveis com a equidade.

Esta complexidade pode porém ser reduzida.

Iníquo é o que contraria a Justiça.

A desvantagem exagerada caracteriza justamente a situação de injustiça objectiva. ${ }^{17}$

A lesão da equidade é ainda lesão da Justiça. Mas caracteriza-se por ser a Justiça do caso concreto: permite a apreciação de todas as circunstâncias do caso, o que em geral não é permitido.

Há contradição no recurso simultâneo à Justiça e à equidade. No concurso de ambas, a equidade prevalece, porque permite a consideração de aspectos particulares do caso. Realiza-se a Justiça de forma mais concretizadora que a habitual.

Isto significa que os três primeiros critérios se reduzem afinal a uma apreciação pela equidade.

Resta a contrariedade à boa-fé. Mas sobre este critério alternativo falaremos em particular no número seguinte. Veremos que o critério deve ser afinal rejeitado e que o único critério geral a reter é o da Justiça, na sua manifestação pela equidade.

A equidade é apenas o critério da valoração de casos não especificados. No que respeita às verdadeiras especificações constantes das restantes alíneas, já o critério não é o da equidade, mas o da injustiça objectiva da situação. Assim, a cláusula que estabeleça inversão do ónus da prova em prejuízo do consumidor (inc. VI) é nula sem mais, independentemente de qualquer apreciação das circunstâncias do caso concreto.

O critério geral do inc. IV ainda nos dá outro ensinamento, na medida em que condena as obrigações que coloquem o consumidor em "desvantagem exagerada".

17 A "vantagem exagerada" é esclarecida no $\S 1^{\circ}$, mas de modo pouco satisfatório. No inc. I caracterizase por ofender os princípios fundamentais da ordem jurídica, o que pela sua vacuidade não diz nada e leva a confundir com a cláusula ilícita; no inc. II fala-se em restringir direitos fundamentais inerentes à natureza do contrato, expressão que é afim da usada no art. $424 \mathrm{NCC}$, que já comentámos no número anterior; no inc. III fala-se em se mostrar excessivamente onerosa para o consumidor, o que é um sinónimo de exageradamente desvantajosa. Há todavia alguns aspectos úteis a anotar. $\mathrm{O}$ inc. II fala em ameaçar "o equilíbrio contratual", o que mostra que é a questão do equilíbrio ou proporção, logo da Justiça, que está em causa. $\mathrm{O}$ inc. III manda atender às circunstâncias peculiares do caso, o que aponta para a recondução à equidade, que apontaremos a seguir. 
Não é qualquer desvantagem que pela cláusula é proibida porque abusiva. É necessário que essa desvantagem seja exagerada. Intervém aqui uma consideração de segurança, que impede que qualquer desproporção seja relevante para o direito.

Com efeito, seria inviável que todo o negócio pudesse ser posto em causa, por invocação dum desequilíbrio no seu conteúdo. A instabilidade social criada seria devastadora, e nenhum sistema judicial poderia suportar a conflituosidade daí resultante. Por isso a lei exige a desvantagem exagerada. É necessário que a desproporção seja manifesta para que a repressão das cláusulas abusivas seja actuada.

Este princípio é generalizável a todas as cláusulas proibidas que se fundem na injustiça do conteúdo.

\section{A BOA-FÉ: UM PSEUDOCRITÉRIO}

Pode suscitar-se, como critério alternativo ao da Justiça (ou da equidade), o critério geral da boa-fé. Seria abusiva a cláusula que contrariasse os princípios da boa-fé.

Este recurso surge em várias legislações. O critério geral da lei portuguesa exprime-se mesmo assim: "São proibidas as cláusulas contratuais gerais contrárias à boa-fé". ${ }^{18} \mathrm{E}$, no que respeita às cláusulas abusivas, o mesmo critério fundamental foi adoptado pela Directriz da Comunidade Europeia n ${ }^{\circ} 93 / 13$, de 5 de Abril, ${ }^{19}$ e é seguido por vários Estados-membros.

Supomos porém que o recurso à boa-fé é meramente semântico, e não abrange na realidade esta situação.

O critério da boa-fé, para cobrir o domínio das cláusulas contratuais gerais, foi adoptado pela jurisprudência alemã, quando não havia lei a que se arrimasse. Procurouse então o refúgio numa cláusula geral. Tendo-se hesitado entre a boa-fé e os bons costumes, acabou por se preferir a boa-fé. Quando surgiu depois, a AGBGesetz recolheu estes antecedentes e fixou a boa-fé como cláusula geral.

O critério irradiou deste modo para outros países europeus. Mais tarde, quando se deu a intervenção comunitária no domínio das cláusulas abusivas, a afinidade de situações levou a que se adoptasse também como critério geral a boa-fé.

São estes possivelmente os antecedentes da lei brasileira, tal como da portuguesa. Mas não parece serem justificativos.

A boa-fé pode ser objectiva ou subjectiva. Mas como critério de valoração de cláusulas contratuais, só a boa-fé objectiva pode estar em causa. ${ }^{20}$

A boa-fé objectiva manifesta-se em regras de conduta, que fixem o correcto comportamento inter-relacional. Ora, este esquema é aqui totalmente inaplicável. Não

18 Art. 15 do Dec.-Lei n. ${ }^{\circ}$ 446/85, de 25 de outubro, sobre cláusulas contratuais gerais.

19 Art. 3/1. Esta directriz, que regula as cláusulas abusivas, caracteriza-as por, a despeito da exigência de boa-fé, se originar um desequilíbrio significativo em detrimento do consumidor. Tem a curiosidade de cumular desequilíbrio objectivo e inobservância da boa-fé.

20 Não há matéria ou estado subjectivo a avaliar. Nomeadamente, o mal não está na exigência do cumprimento. Se a obrigação fosse válida, a exigência seria impecável. O não poder exigir é mera decorrência da invalidade da cláusula. 
se fixam padrões de conduta, antes de julgam cláusulas objectivas para concluir se elas devem ou não ser rejeitadas perante a ordem jurídica.

Que o critério se tivesse desenvolvido na Alemanha antes de haver lei compreendese, como um mero recurso para suprir justamente essa falha de lei: foi uma entorse científica para obter um resultado prático. Mas o que se não compreende é que o critério tenha subsistido uma vez sobrevinda a lei. E menos ainda, que tenha passado para leis estrangeiras, justamente quando o bordão da boa-fé se tornava totalmente dispensável, por haver já lei em que se apoiar.

O critério geral estava agora contido na lei: era o da desproporção ou desequilíbrio criado nas situações. Era, em palavras mais simples, a injustiça da situação criada.

Por que não se reconheceu então a realidade, e se operou a fuga para a boa-fé, apesar do seu carácter falacioso deste recurso?

Porque o subjectivismo reinante impunha uma roupagem subjectiva, ainda que a cobrir uma realidade objectiva.

Mas esse é aspecto que será considerado a final. Por agora, fica confirmado que o único critério utilizável é o da Justiça, na sua manifestação como equidade.

\section{O ENUNCIADO LEGAL}

A análise das previsões legais levaria a um casuísmo que seria deslocado empreender aqui. Limitamo-nos ao que possa ter carácter ainda comum.

Como observação geral, notamos uma certa confusão entre cláusulas abusivas e cláusulas ilícitas. As cláusulas violadoras de disposição legal são ilícitas: nada adianta incluí-las entre as cláusulas abusivas, e só dificulta a determinação do que sejam estas cláusulas. É o que se passa com a previsão do art. 51 inc. XIV - as cláusulas que infrinjam normas ambientais. Ou ainda com o inc. II - as cláusulas que subtraiam ao consumidor a opção de reembolso da quantia já paga a que tiver direito. Deles resultará quando muito a cominação de nulidade para uma infracção que estava já prevista por outra norma.

Limitando-nos às restantes, poderiam fazer-se várias classificações. A lei portuguesa distingue as cláusulas proibidas consoante surgem nas relações com consumidores e entre empresários. Descodificando, diremos que há uma rede mais apertada que representa o regime comum das cláusulas abusivas, e uma rede de malha mais larga restritamente aplicável nas relações entre empresários, que se considera não carecerem de tanta protecção.

Esta distinção não tinha até agora correspondente na lei brasileira. Mesmo a generalização operada pelo art. 29 do Código do Consumidor só beneficiava quem estivesse sujeito às práticas comerciais previstas, pelo que dificilmente abrangeria os empresários que agissem como tal. Com o novo Código Civil, toda a questão terá de ser reponderada.

A lei portuguesa distingue ainda, dentro de cada categoria, as cláusulas absoluta e relativamente proibidas. As primeiras são taxativas, as segundas são adoçadas por 
uma valoração complementar: excessivo, sem justificação, sem contrapartida adequada etc.

A lei brasileira é pouco sensível a proibições relativas. Mas não as desconhece de todo. Assim, o art. 51 inc. I do Código do Consumidor permite limitar a indemnização devida pelo fornecedor ao consumidor - pessoa jurídica "em situações justificáveis".

As proibições constantes deste preceito são ainda susceptíveis de vários agrupamentos. Podem ter por fundamento:

1) o desequilíbrio das posições das partes, por atribuírem poderes unilaterais ao fornecedor

É o caso dos incs. IX a XIII.

2) a ablação de direitos do consumidor

É o caso dos incs. I a III. ${ }^{21}$

3) a imposição de obrigações fora das normais à parte não fornecedora

É o caso dos incs. VII e VIII.

Na prática, as cláusulas mais frequentes são as cláusulas de irresponsabilidade (ou de limitação da responsabilidade) e as que invertem o ónus da prova em detrimento do consumidor. ${ }^{22}$

Curiosamente, uma cláusula que tem grande ocorrência e significado em Portugal - a cláusula da alteração das regras do risco - não é contemplada no Código do Consumidor.

As relações financeiras têm uma disciplina especial no art. 52 do Código do Consumidor. Mas note-se que as obrigações que se estabelecem no corpo do artigo são obrigações de informação. A orientação tem sido desenvolvida em legislação financeira avulsa, favorecida possivelmente pela tese que pretende que o desequilíbrio entre fornecedor e consumidor é colmatado pela informação do consumidor. Fornecida esta, o princípio da autonomia da vontade já podia retomar o seu império.

\section{EFEITO SOBRE O CONTRATO DA EXISTÊNCIA DE CLÁUSULA EM INFRACÇÃO}

Qual a sorte do contrato, se se detecta nele uma cláusula em infracção?

Não é necessário recorrer aos princípios gerais, porque há disposições específicas neste domínio.

Há que distinguir duas modalidades: 
- as cláusulas que não se chegam a integrar no contrato

- as cláusulas abusivas.

1) Cláusulas que não se chegam a integrar no contrato

São as cláusulas excluídas por não ter sido dado conhecimento delas, nos devidos termos, aos destinatários.

A consequência é aqui a de os contratos não obrigarem os consumidores (art. 46 do Código do Consumidor). Mas não se torna expresso qual o vício que está em causa.

2) Cláusulas abusivas

A cláusula é nula (art. 51, proémio). Mas o $\S 2^{\circ}$ esclarece que a nulidade da cláusula não invalida o contrato.

Portanto, o caminho para que aponta é o da redução legal. O contrato subsiste, mas depurado da cláusula inquinada. Não há sequer que atender à vontade real ou tendencial das partes, que seria de regra segundo o art. $184 \mathrm{NCC}$, porque a lei comanda autoritariamente a produção do efeito redução.

Mas a lei estabelece um limite. O contrato é inválido quando a supressão da cláusula, apesar dos esforços de integração, importar ónus excessivo para qualquer das partes.

Daqui decorre que, ocorrendo cláusula nula, a primeira tarefa que se impõe é a de integrar o contrato, substituindo essa cláusula. Se isso não for possível, ou se daí derivar em todo o caso ónus excessivo, então o contrato é irremediavelmente nulo.

Mas esclarece-se que o ónus excessivo relevante pode recair sobre qualquer das partes. Aqui o Código abandona a sua parcialidade em relação ao consumidor e atende também ao ónus excessivo do fornecedor. Justificadamente, porque o ónus excessivo é injusto, seja qual for a parte que grave.

A lei não estabelece disciplina análoga para o caso de a cláusula não se ter chegado a integrar no contrato. Mas pode acontecer do mesmo modo que o contrato, sem aquela cláusula, traga um ónus excessivo para qualquer das partes. Haverá então que aplicar por analogia a previsão do art. $51 \S 2^{\circ}$, porque há a mesma razão de decidir.

\section{AS LIMITAÇÕES DO SISTEMA CIVIL}

Formos percorrendo os vários regimes que permitem a interligação dos três institutos que estudamos. Vimos que há pontos de confluência, mas há também diferenças irredutíveis.

Confirmamos que o instituto das cláusulas negociais gerais nunca chegou a ser acolhido na ordem jurídica brasileira. Regras que lhe são especificamente dirigidas noutras ordens jurídicas, como a criação dum registo específico de cláusulas contratuais gerais proibidas, são impensáveis no Brasil. Mas nem por isso as cláusulas contratuais gerais deixam de estar ínsitas na disciplina dos contratos de adesão; tal como participam da listagem das cláusulas abusivas, se o seu conteúdo for abusivo. 
Quanto às cláusulas abusivas, apesar de a sua génese estar no Direito do Consumidor, foram objecto dum processo de generalização. Podem hoje ser entendidas como categoria aberta, o que permite o desenvolvimento progressivo da matéria.

Mas justamente neste ponto há que estar prevenido, para não criar uma ideia errada do que representa esta generalização. Não podemos supor que a matéria das cláusulas abusivas saltou do Código do Consumidor para o Código Civil, para se tornar um instituto comum, de que todas as pessoas participam igualmente.

Não é assim, porque há duas ordens de restrições.

1) Por um lado, nem todas as regras disciplinadoras das cláusulas abusivas são transferíveis para o Direito Civil.

Como tivemos oportunidade de verificar, há certas regras que só se fundam na protecção do consumidor, pelo que são resistentes a uma generalização.

Outras regras não foram nunca declaradas extensivas aos não consumidores. Assim, o art. $6 \mathrm{~V}$ do Código do Consumidor, que proclama direito básico "a modificação das cláusulas contratuais que estabeleçam prestações desproporcionais" ${ }^{23}$ Esta regra, cuja conjugação com as regras do Capítulo VI provoca aliás consideráveis dificuldades, não foi objecto de nenhuma cláusula de generalização.

Isto significa que os não consumidores, pelo menos a uma primeira vista, não têm acesso à possibilidade de modificação de cláusulas abusivas.

2) Por outro lado, a generalização das regras a pessoas que não são consumidoras não significa a sua universalização.

Como temos observado, a generalização que o art. 29 do Código do Consumidor opera faz-se em benefício das pessoas, "determináveis ou não, expostas às práticas" previstas.

E essas práticas são práticas das entidades fornecedoras (cfr. art. 39, por exemplo).

Isto significa que as regras continuam a ser unilaterais, ainda que não beneficiem apenas consumidores. Os fornecedores, agindo como tal, não poderão beneficiar delas nas relações que entre si estabeleçam, invocando por exemplo a desvantagem exagerada. Terão de recorrer aos princípios gerais do direito.

Nem sequer há uma disciplina autónoma das cláusulas usadas nas relações entre fornecedores, ao contrário do que acontece no direito português. Isto é consequência de a figura da cláusula contratual geral não ter sido por si objecto de regulação na ordem jurídica brasileira.

Donde resulta que, mesmo explorando todas as potencialidades de expansão das previsões legais, não é possível chegar a um sistema integrado na disciplina das cláusulas abusivas. O sistema civil - que não o do consumidor - está ainda por completar.

Mas isto é uma inversão, porque o que caracteriza antes de mais as pessoas é serem cives, cidadãos, e não consumidores.

23 Além da sua revisão em razão de factos supervenientes que as tornem excessivamente onerosas. Mas neste caso há que considerar o disposto sobre a resolução do contrato por onerosidade excessiva, nos arts. 478 a 480 NCC. 


\section{SUPERAÇÃO DO VOLUNTARISMO?}

Partimos da demonstração que o nosso sistema é tributário do voluntarismo, triunfante a partir do séc. XVIII.

Mas vimos também que, neste como aliás em muitos outros sectores, se foram introduzindo correcções no modelo dominante, em que voltava a pairar, mais ou menos declarada, a preocupação pela Justiça do conteúdo.

O séc. XX terá encerrado um ciclo? O ponto de gravidade estará sendo deslocado de novo, da vontade para a Justiça do conteúdo?

Não há decerto um movimento que se afirme com essa finalidade. Mas em muitos sectores se chega igualmente à conclusão que situações manifestamente injustas não podem merecer protecção jurídica.

O novo Código Civil trouxe vários contributos ao domínio da relevância decisiva do conteúdo.

Prevê por exemplo a lesão, no art. 157.

Regula a onerosidade superveniente excessiva, nos arts. 478 a 480.

No que nos importa, regula o contrato de adesão e não fecha a porta à recepção da disciplina das cláusulas abusivas, através da relevância dada à desproporção ou desequilíbrio objectivo das prestações.

Até onde se pode chegar por este caminho?

Além das fronteiras a atribuir às cláusulas abusivas, não estará em germe um princípio mais radical, que se poderia enunciar assim: a manifesta injustiça do conteúdo retira à situação validade ou eficácia?

Este é um movimento em marcha, nalguns pontos até muito adiantado em vários países. no Brasil.

Há agora condições, com o novo Código Civil, para suscitar a questão também

A resposta não pode ser imediata. Tem de ser estruturada na análise de numerosas situações em que as consequências jurídicas normais sofrem embates em consequência da desproporção ou desequilíbrio das situações em presença.

E deve prolongar-se ainda na pesquisa de todo o regime jurídico que conseqüentemente lhes fica associada.

Mas isto é já outra linha de indagação. Por ora, basta ter deixado a porta entreaberta. 